
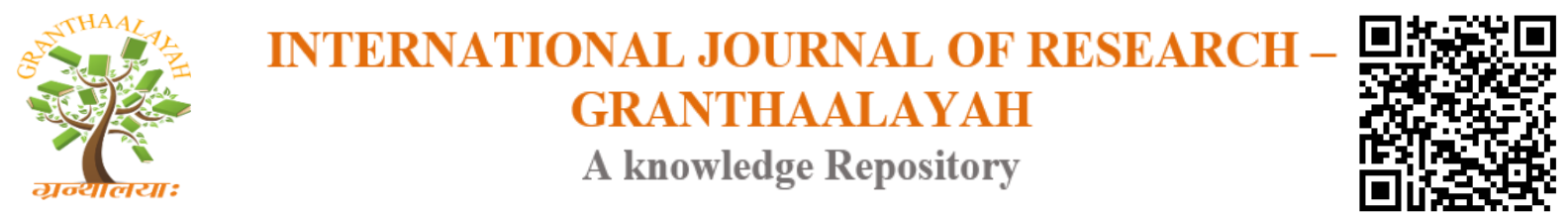

Science

\title{
THE MICROBIOLOGICAL STUDY OF MINCED MEAT IN SOME MARKETS IN ALEXANDRIA WITH REFERENCE TO ESCHERICHIA COLI 0157 H: 7
}

\author{
Aiada Daw Mohamed ${ }^{* 1}$ \\ ${ }^{* 1}$ Department of Laboratory, Medical Technology College, Bani Waleed University, Libya
}

\begin{abstract}
This cross sectional study was carried out during a four months period from December, 2012 to March, 2013. A total of 140 fresh and frozen ground beef samples were purchased from local butchers and supermarkets in Alexandria. Each of the ground beef sample was analyzed for its microbiological quality (Aerobic plate count, total coliform count and E. coli count) as well as for the presence of E. coli O157:H7. Out of the 140 studied ground meat samples, 75(53.6\%) proved to be unsatisfactory according to the three tested parameters. None out of 140 examined ground meat samples showed E. coli O157:H7.
\end{abstract}

Keywords: Microbiological Quality; Ground Meat; APC; TCC And E. coli O157:H7.

Cite This Article: Aiada Daw Mohamed (2017). "THE MICROBIOLOGICAL STUDY OF MINCED MEAT IN SOME MARKETS IN ALEXANDRIA WITH REFERENCE TO ESCHERICHIA COLI O157 H: 7." International Journal of Research - Granthaalayah, 5(9), 26-35. https://doi.org/10.29121/granthaalayah.v5.i9.2017.2194.

\section{Introduction}

Meat is considered as the most nutritive source of protein consumed by humans [1]. Most meat have high water content corresponding to the water activity of approximately 0.99 , which is suitable for microbial growth [1]. It also contains sufficient nutrients needed to support the growth of microorganisms [2].Among the factors that affect microbial growth in meat are intrinsic properties (physical and chemical properties of meat) and extrinsic environmental factors; [3]. However the factors having the greatest influence on the growth of microorganisms in meat and meat products are the storage temperatures, moisture and oxygen availability [4].

In fact, tissues from healthy animal are sterile, however it has been pointed out that during slaughter, dressing and cutting, microorganisms come chiefly from the animal and its intestinal tract, but more are added from knives, cloths, air, carts and equipment in general. [5]. Turtura (1991) reported that the most frequently Gram negative bacilli identified on meat were Citrobacter freundii (C. freundii), Escherichia coli (E. coli), Enterobacter agglomerans (En. agglomerans), and the less frequently isolated strains are of the genera Klebsiella, Shigella and 
Proteus. E. coli and Staphylococcus aureus (S. aureus) are normal flora in human and animals, their presence in foods are indications of excessive human handling [6].

Ground meat is not only highly susceptible to spoilage, but also is frequently involved in the spread of pathogens, [7].which are major causes of illness and death worldwide [8]. It is resulting from ingestion of bacteria, toxins and cells produced by microorganisms present in food [6]. Recognizing this, the World Health Organization (WHO) developed its Global Strategy for Food Safety [9].The microbiological safety of food is achieved by as far as possible ensuring the absence of pathogenic microorganisms and by all means preventing their multiplication [10].

Aerobic plate counts (APC) often are chosen as an indicator of the effectiveness of Hazard Analysis Critical Control Point (HACCP) plans, because data for all aerobic bacteria are more easily collected than data for pathogens of concern or other indicator organisms [11]. A common practice is to use tests for coliform, including E. coli for screening and if there is reason to determine the likelihood of fecal contamination, the total coliform count (TTC) or other Enterobacteriaceae are subjected to further tests to establish whether any of them are E. coli [12].

\section{Material and Methods}

Sample collection: One hundred grams of ground meat were obtained from worker in collection sites and placed in the food collection bags. Sample source and sample number was identified on sample form. Refrigeration of sample was used during transport. Frozen samples were kept frozen. A submission form for each sample was filled out including: type of meat and its color; date and locality of the collection site; name of butcher and its personal hygiene and sanitary condition of the shop.

Sample preparation: Ten gram of each sample were weighted and transferred to a stomacher bag under aseptic conditions. The sample was then diluted to a $10^{-1}$ dilution with $90 \mathrm{ml}$ of peptone water and homogenized for 2 min by using a Stomacher. Following homogenization, ten-fold serial dilutions for each sample were made in sterile peptone water up to $10^{-4}$, by transferring $1 \mathrm{ml}$ of previous dilution to $9 \mathrm{ml}$ of peptone water.

\subsection{Microbiological Analysis}

Aerobic Plate Count: One $\mathrm{ml}$ of each dilution was pipette into separate, appropriately marked Petri dish and to each plate, $12-15 \mathrm{ml}$ plate count agar (cooled to $45 \pm 1^{\circ} \mathrm{C}$ ) was added within 15 min of the original dilution. After Petri dishes solidified were incubated promptly for $48 \pm 2 \mathrm{~h}$ at $35^{\circ} \mathrm{C}$. Plates with colony number between 30-300 colony-forming units (CFU) were selected, coun++ted and multiplied by the dilution factor to calculate CFU/gram of ground meat.

Determination of coliform and $E$. coli using the Most Probable Number (MPN) method: One $\mathrm{ml}$ of each dilution was cultured in the Lauryl Sulphate Tryptose broth (LST) tubes for determining the presence of coliform and the positive LST tubes showing gas were subcultured into Brilliant Green Bile (BGB) broth and EC broth. All positive BGB tubes recorded as confirmed MPN of coliform bacteria per gram of ground meat, however gas production in the 
EC tubes was considered a confirmed test for fecal coliform organisms and subcultured onto Eosin Methylene Blue (EMB) agar plates which incubated for $24 \mathrm{~h}$ at $35^{\circ} \mathrm{C}$ and examined for green metallic sheen colonies and then transfered to IMViC (Indole, Methyl red,VoguesProskauer and Citrate) tubes. MPN of $E$. coli per gram were computed considering producing ++-- or-+-- IMViC patterns.

Determination for Escherichia coli 0157:H7 (E. coli 0157:H7): The presence of E. coli O157:H7 were detected in ground meat samples by preenriched with modified novobiocin EC broth at $37 \mathrm{C}^{0}$ for $24 \mathrm{~h}$. The dilution was inoculated onto Sorbitol MacConkey's Agar (SMA) and incubated at $37^{\circ} \mathrm{C}$ for $24 \mathrm{~h}$. At the end of incubation, colorless, sorbitol negative colonies were subjected to E. coli $\mathrm{O} 157: \mathrm{H} 7$ test latex.

\section{Results}

The results of this study were recorded according to the Commission of the European Communities [13] and the Egyptian guidelines [14,15] as satisfactory, acceptable and unsatisfactory. Out of the 140 studied ground meat samples, 75(53.6\%) proved to be unsatisfactory according to the 3 tested parameters. None out of 140 examined ground meat samples showed E. coli O157:H7. The following tables and figures illustrate the results of this study:

Table (1) shows the distribution of the 140 examined ground meat samples according to their microbiological quality.

Regarding the microbiological quality of the studied 140 examined ground meat samples, the APC parameter showed that 57(40.7\%) were satisfactory, 48(34.3\%) were acceptable and $35(25.0 \%)$ were unsatisfactory. The corresponding figures according to the TCC parameter were $37(26.4 \%), 49(35.6 \%)$ and $54(38.6 \%)$ respectively and those according to the E. coli count $67(47.9 \%), 51(36.4 \%)$ and $22(15.7 \%)$ respectively.

The collective means \pm standard deviation of APC, TCC and E. coli count were $4.1 \times 10^{6} \pm 7.2 \times 10^{6} \mathrm{cfulg}, 1.02 \times 10^{4} \pm 2.2 \times 10^{4} \mathrm{cfu} / \mathrm{g}$ and $1.9 \times 10^{3} \pm 1.2 \times 10^{4}$ cfulg respectively.

Table 1: Distribution of the 140 examined ground meat samples according to their microbiological quality, Alexandria, 2013.

\begin{tabular}{|c|c|c|c|c|c|c|c|}
\hline \multirow{3}{*}{ Parameter } & \multicolumn{7}{|c|}{ Microbiological quality of ground meat } \\
\hline & \multicolumn{2}{|c|}{ Satisfactory } & \multicolumn{2}{|c|}{ Acceptable } & \multicolumn{2}{|c|}{ Unsatisfactory } & \multirow{2}{*}{$\begin{array}{l}\text { Mean } \pm \text { SD } \\
\text { CFUlg }\end{array}$} \\
\hline & No. & $\%$ & No. & $\%$ & No. & $\%$ & \\
\hline APC & 57 & 40.7 & 48 & 34.3 & 35 & 25.0 & $4.1 \times 10^{6} \pm 7.2 \times 10^{6}$ \\
\hline TCC & 37 & 26.4 & 49 & 35.6 & 54 & 38.6 & $1.02 \times 10^{4} \pm 2.2 \times 10^{4}$ \\
\hline E. coli & 67 & 47.9 & 51 & 36.4 & 22 & 15.7 & $1.9 \times 10^{3} \pm 1.2 \times 10^{4}$ \\
\hline
\end{tabular}




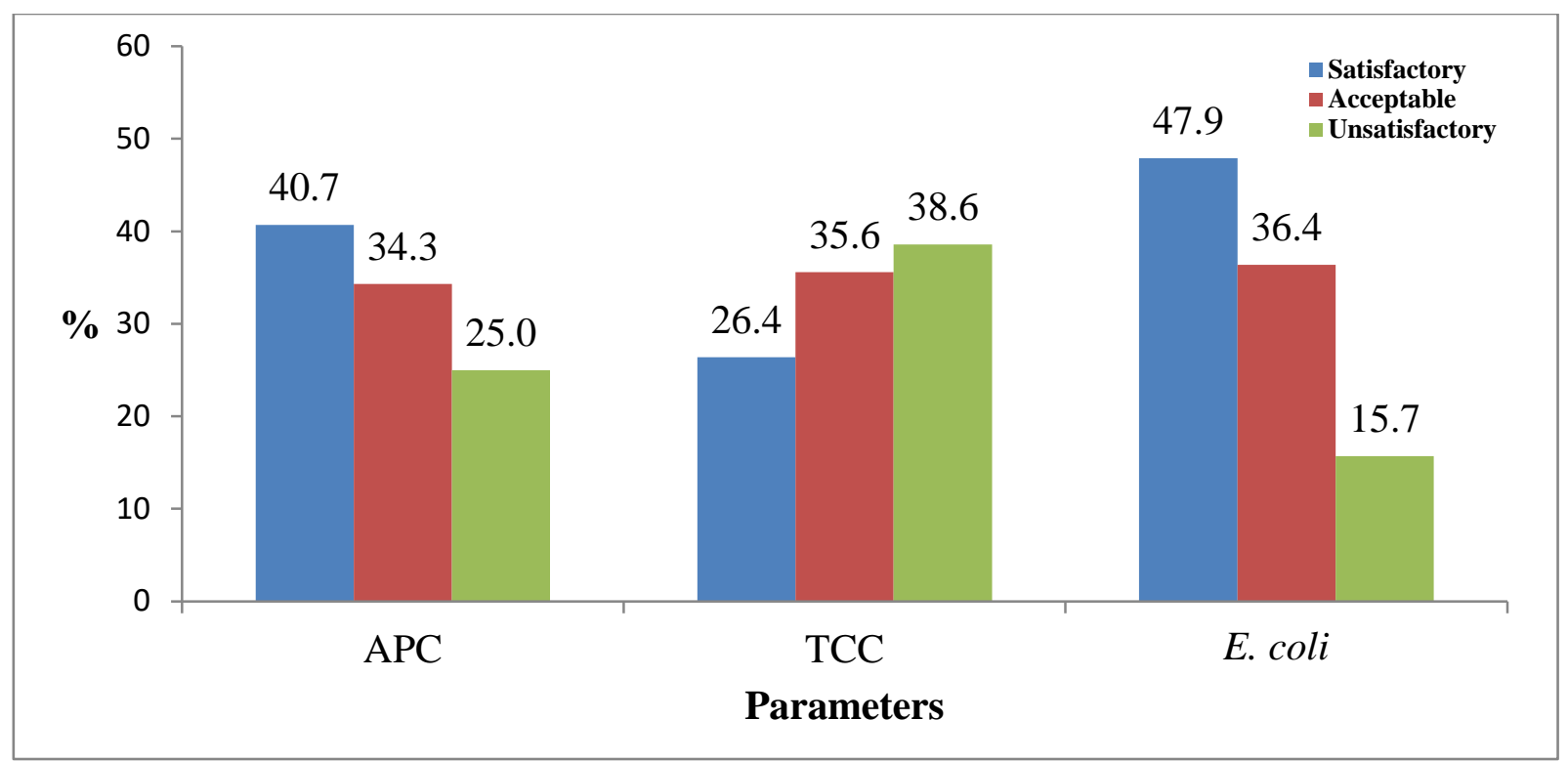

Figure 1: Distribution of the 140 examined ground meat samples according to their microbiological quality, Alexandria, 2013.

Tables 2 a, b and $\mathbf{c}$ show the comparison between microbiological quality of the examined ground meat samples according to their APC ,TCC and E. coli.

Table 2 a shows that both the APC and TCC parameters agreed in the results of 68(48.6\%) samples as either satisfactory or acceptable, and 17(12.1\%) samples as unsatisfactory. On the other hand, 37(26.4\%) samples which proved to be unsatisfactory according to their TCC were either satisfactory or acceptable according to their APC; and 18(12.9\%) samples that proved to be either satisfactory or acceptable by the TCC were unsatisfactory by the APC. The difference between these results was found to be statistically significant. $(\mathbf{p}=\mathbf{0 . 0 1 4})$.

Table $2 \mathrm{~b}$ shows that both the APC and E. coli parameters agreed in the results of 91(65.0\%) samples as either satisfactory or acceptable, and 8(5.7\%) samples as unsatisfactory. On the other hand, 14(10.0\%) samples which proved to be unsatisfactory according to their E. coli were either satisfactory or acceptable according to their APC; and 27(19.3\%) samples that proved to be either satisfactory or acceptable by the $E$. coli count were unsatisfactory according to their APC. The difference between these results was found to be not statistically significant. $(\mathbf{p = 0 . 0 6 0 )}$.

Table $2 \mathrm{c}$ shows that both the TCC and E. coli parameters agreed in the results of 83(59.3\%) samples as either satisfactory or acceptable, and 19(13.6\%) samples as unsatisfactory. On the other hand, 3(2.1\%) samples which proved to be unsatisfactory according to their E. coli were either satisfactory or acceptable according to their TCC; and 35(25.0\%) samples that proved to be either satisfactory or acceptable by the $E$. coli count were unsatisfactory according to their APC. The difference between these results was found to be statistically significant. $\quad(\mathbf{p}=\mathbf{0 . 0 0 0})$. 
Table 2: Comparison between microbiological qualities of examined ground meat samples according to their parameters.

\section{a. APC versus TCC parameters.}

\begin{tabular}{|l|l|l|l|l|l|l||}
\hline \multirow{3}{*}{ APC } & \multicolumn{6}{|l|}{ Microbiological quality of ground meat } \\
\cline { 2 - 8 } & \multicolumn{2}{|l|}{$\begin{array}{l}\text { Satisfactory } \\
\text { Acceptable }\end{array}$} & Unsatisfactory & \multicolumn{2}{l|}{ Total } \\
\cline { 2 - 8 } & No. & $\%$ & No. & $\%$ & No. & $\%$ \\
\hline $\begin{array}{l}\text { Satisfactory } \\
\text { Acceptable }\end{array}$ & 68 & 48.6 & 37 & 26.4 & 105 & 75.0 \\
\hline Unsatisfactory & 18 & 12.9 & 17 & 12.1 & 35 & 25.0 \\
\hline Total & 86 & 61.4 & 54 & 38.6 & 140 & 100.0 \\
\hline
\end{tabular}

b. APC versus $E$. coli parameters.

\begin{tabular}{|c|c|c|c|c|c|c|}
\hline \multirow{3}{*}{ APC } & \multicolumn{6}{|c|}{ "Microbiological quality of ground meat } \\
\hline & \multicolumn{2}{|c|}{$\begin{array}{l}\text { Satisfactory } \quad+ \\
\text { Acceptable }\end{array}$} & \multicolumn{2}{|c|}{ Unsatisfactory } & \multicolumn{2}{|c|}{ Total } \\
\hline & No. & $\%$ & No. & $\%$ & No. & $\%$ \\
\hline $\begin{array}{l}\text { Satisfactory } \\
\text { Acceptable }\end{array}$ & 91 & 65.0 & 14 & 10.0 & 105 & 75.0 \\
\hline Unsatisfactory & 27 & 19.3 & 8 & 5.7 & 35 & 25.0 \\
\hline Total & 118 & 84.3 & 22 & 15.7 & 140 & $\overline{100.0}$ \\
\hline
\end{tabular}

c. TCC versus $E$. coli parameters.

\begin{tabular}{|c|c|c|c|c|c|c|}
\hline \multirow{3}{*}{ TCC } & \multicolumn{6}{|c|}{ Microbiological quality of ground meat } \\
\hline & \multicolumn{2}{|c|}{$\begin{array}{ll}\text { Satisfactory }+ \\
\text { Acceptable }\end{array}$} & \multicolumn{2}{|c|}{ Unsatisfactory } & \multicolumn{2}{|c|}{ Total } \\
\hline & No. & $\%$ & No. & $\%$ & No. & $\%$ \\
\hline $\begin{array}{l}\text { Satisfactory } \\
\text { Acceptable }\end{array}$ & 83 & 59.3 & 3 & 2.1 & 86 & 61.4 \\
\hline Unsatisfactory & 35 & 25.0 & 19 & 13.6 & 54 & 38.6 \\
\hline Total & 118 & 84.3 & 22 & 15.7 & 140 & 100.0 \\
\hline
\end{tabular}

\section{Discussion}

Because of its high bacterial level, and its likelihood of keeping pathogenic bacteria, ground meat is an important meat product that threatens human health [16].

Contamination with spoilage microorganisms may lead to product and economic losses, while presence of pathogens or their toxins may be the cause of foodborne disease that may lead to loss of human life [17].

Narasimha and Ramesh [18]. Suggest that minced meat of better microbiological quality might be obtained if animals were processed on a small scale with further care during mincing of the meat. The retail grinder was assumed to randomly mix the pathogen throughout the $5 \mathrm{~kg}$ lot of ground beef. Extensive contamination, or abusive conditions of handling and storage that allow 
microbial proliferation, increase the potential for presence of pathogenic bacteria and formation of toxins, and may lead to product spoilage and public health problems [19,20].

APC are a widely accepted measure of the general degree of microbial contamination.(21) Meat is generally considered of poor hygienic quality or unfit for consumption when the APC exceeds $10^{6} \mathrm{cfu} / \mathrm{g}$. Mohammad et al [22] in Pakistan pointed out the bacterial count exceeding $10^{5} \mathrm{lg}$ in delicatessen food products are indicative of dangerous contamination. However Gil et al [23] proved that samples of minced meat contaminated with APC of $6 \log _{10}$ cfulg indicates a deterioration process with off odor and reduction of shelf life and when contamination reach 7 $\log _{10}$ cfulg slime formation is already evident.

In the present study the mean of total aerobic plate count of the 140 examined ground meat samples were $4.1 \times 10^{6} \mathrm{cfu} / \mathrm{g}$. Almost similar results at the average levels of $10^{6} \mathrm{cfu} / \mathrm{g}$ were reported by Khalafalla et al [24] Higher results of $7.2 \times 10^{8}$ cfulg were reported by Mousa et al (25).On other hand much lower results were reported by Elmali and Yaman (26) at the average of $3.4 \times 104$ cfulg.

According to the Commission of the European Communities and the Egyptian guidelines, to be unsatisfactory, ground meat samples should contain $>10^{6} \mathrm{cfu} / \mathrm{g}$, this figure was recorded in this study in only $25.0 \%$ of the studied samples. This percentage was relatively low when compared to those reported in Istanbul, Turkey by Cetini et al [16] who found the APC to be above the given limits in $66 \%$ of their samples. Also in a study reported by Duitschaever et al [27], they found APC in $64 \%$ of ground meat samples with counts more than $>10^{6} \mathrm{cfu} / \mathrm{g}$. Even higher percentages reaching 79\% and 75\% were reported by Siriken et al [28] in Turkey and Heredia et al [29] in Mexico respectively, however these studies took the $10^{5}$ limit as being unsatisfactory. APC provides an estimate of overall bacterial populations. Higher APC usually relates to poorer quality and a reduced shelf life, but the relationship between APC and concentration of foodborne pathogens in raw meats is unclear [30].

Microbial indicators are more often employed to assess food safety and sanitation than quality. They may be employed to reflect the microbiological quality of foods relative to product shelf life or their safety from foodborne pathogens [31,32]. The collective mean of microbial contamination of ground beef with TCC in this study was $1.02 \times 10^{4}$ cfulg denoting low sanitary level. These include $38.6 \%$ recorded as unsatisfactory according to the European Communities and the Egyptian guidelines. Similar results to this mean value was reported in Oklahoma in United States by Davidson et al [33], who found the TCC mean level of $1.2 \times 10^{4} \mathrm{cfu} / \mathrm{g}$. Much lower results were reported in Turkey by Elmali and Yaman [26] at an average of 2.0x10 $0^{1} \mathrm{cfu} / \mathrm{g}$. While higher results also in Turkey were reported by Sancak et al [34] who found that the average numbers of TCC were $4.0 \times 10^{6} \mathrm{cfulg}$. The previous unsatisfactory percentage is considered much lower than the 64.3\% reported in Turkey by Siriken et al [28] even when their unsatisfactory criteria was $>1100 \mathrm{cfu} / \mathrm{g}$, which is higher than the $>1000$ adopted in the present study.

According to Gill et al [23], the counts of E. coli increase steadily (more than 3 log unit) during the various stages of carcass handling and deboning process. Such increases in contamination become further aggravated with poor hygienic conditions during processing. In the present study 
the collective mean of $E$. coli count were $1.9 \times 10^{3} \mathrm{cfulg}$. This result come in agreement with Davidson et al (33) in Oklahoma, United States who reported E. coli at the level of $4.8 \times 10^{3}$ cfulg, while much lower results of $5.0 \times 10^{\circ} \mathrm{cfulg}$ were reported by Westhoff and Feldstein [35].

Much higher results in Ankara, Turkey were reported by Tekinsen et al [36] who examined 20 ground meat samples and found E.coli at the average levels of $4.2 \times 10^{6}$. However high counts of E. coli in foods are not always alarming because most strains are harmless and opportunistic in nature. [37]. Nevertheless, the bacterium is well recognized as a fecal indicator that provides a fair estimate of the level of fecal contamination and the hygienic conditions during handling and processing [30].

Meat samples containing $>500$ E. coli $\backslash g$ are considered to be unsatisfactory by the Commission of the European Communities and the Egyptian guidelines; this level was recorded in only $15.7 \%$ of the studied samples. This percentage was relatively low when compared to those reported in Istanbul, Turkey by Cetini et al [16], who observed $36.22 \%$ of their samples to be at the critical limit for their E. coli counts.

The results of this study showed that none of used parameters agreed completely with the other, meaning that the use of only one parameter may show a sample as satisfactory or acceptable, which in the another parameter may forbid its consumption. Therefore, microbiological monitoring using several parameters appears to be a must. Moreover 53.6\% of the total 140 examined ground meat samples were above the safety limits and unfit for human consumption. Higher percentage $(80.7 \%)$ were reported in Morocco by Cohen_et al [38].

The potentially high mortality associated with E. coli O157: H7 strain infection, make its presence in any food material worrisome and of serious public health concern, as most of the outbreaks recorded has been traced to consumption of beef contaminated with the E. coli 0157:H7 strain [39].

In order to assess the risk to human health from E. coli O157:H7 associated with the consumption of ground beef, we examined all samples for prevalence of E. coli O157:H7 and revealed none out of the 140 examined ground meat samples showing it. This result comes in agreement with those of Hinton et al [40] and Hussein [39], they did not detect any E. coli O157:H7 in frozen and fresh meat. However Noveir et al [41] reported that E. coli O157 was isolated in only $0.4 \%$ of their samples, but none of these isolates were found to be $\mathrm{H} 7$ serotype.

Schroeder et al [42] mentioned that E. coli O157:H7 outbreaks due to plants and animal produce have become increasingly common. While half of produce associated outbreaks were due to kitchen-level cross-contamination, which calls for further prevention efforts targeting food preparers, the other half were due to produce already contaminated with E. coli O157:H7 before purchase. [43] So the absence of these bacteria in this study may indicate that the Egyptian animals do not serve as source of contamination with E. coli O157:H7. 


\section{Conclusion}

The ground meat samples were analyzed for determination of their microbiological quality by using APC, TCC and E. coli count as bacteriological parameters. In addition detection of $E$. coli O157:H7 was performed. None out of 140 examined ground meat samples showed E. coli O157:H7. About 53.6\% of the examined ground meat samples were unfit for human consumption.

The difference between APC and E. coli was found to be not statistically significant. $(\mathbf{p}=\mathbf{0 . 0 6 0})$.

\section{References}

[1] Rao VA, Thulasi G, Ruban SW, "Meat quality characteristics of non-descript buffalos as affected by age and sex," World Applied Science Journal, 2009,1058-65.

[2] Magnus P. Meat Composition. Food Science and Technology, $4^{\text {th }}$ edition. Gohumunary Pub: London; 1981. p. 108- 215.

[3] Rombouts FM, Nout R. Food Microbiology and Hygiene. Encyclopedia of Human Biology Academic Press; 1994. P. 661-5.

[4] Forest DC, Harold DA, Judge BA, Robert EA. Different Types of Meat and Meat product consumed by Nigerian. Principle of meat science. Pub. WA. Freeman and Co. pop., 1985; P4178.

[5] Lawrie RA. The preservation effect of smoke on meat. Meat Science Pergaman Press Inc. Maxwell House Fair view park -Elmford: New York; 1984. P. 49-52.

[6] Clarence SY, Obinna CN, Shalom NC. Assessment of bacteriological quality of ready to eat food (Meat pie) in Benin City Metropolis, Nigeria. Afr J Microb Res. 2009; 3(6): 390-5.

[7] Ahmed AM, Ismail TH. Improvement of the quality and shelf-life of minced beef mixed with soy protein by Sage (Saliva officinal is) .African Journal of Food Science. 2010; 4(6): 330 -4.

[8] Adak GK, Meakins SM, Yip H, Lopman BA, O'Brien SJ. Disease risks from foods, England and Wales, 1996-2000. Emerging Infectious Diseases, 2005 March [cited 2009 August 18]. Available from http://www.cdc.gov/ncidod/EID/vol11no03/04-0191.htm.

[9] World Health Organization WHO global strategy for food: safer food for better health. Geneva: The organization; 2002.

[10] Omemu AM, Bankole MO. Ready-to-eat (RTE) vegetable salad: effect of washing and storage temperature on the microbial quality and shel-life. In: the Book of Abstract of the $29^{\text {th }}$ Annual Conference \& General Meeting(Abeokuta 2005) on Microbes as Agents of Sustainable Development, organized by Nigerian Society for Microbiology (NSM), UNAAB, 2005; P 28.

[11] Chong-Hae H, Ewen T, Gyung-Jin B. Aerobic plate counts as a measure of hazard analysis critical control point effectiveness in a pork processing plant. J Food Prot. 2008; 7(16): 1248-52.

[12] Guidelines for Environmental Health Officers on the Interpretation of Microbiological Analysis Data of Food Analysis [Inerent], available from: http://www.doh.gov.za/docs/foodcontrol/trainingmanuals/2011/Guidelines\%20for\%20environme ntal $\% 20$ health $\% 20$ officers $\% 20 \mathrm{on} \% 20$ the $\% 20$ interpretation $\% 20$ of $\% 20$ microbiological $\% 20$ analysi s\%20data\%20of\%20food.pdf [Accessed 2012 November 20].

[13] Kyprianou M. commission of The European Communities, microbiological criteria for foodstuffs, Brussels, C (2005) Available from: http://www.food.gov.uk/multimedia/pdfs/microcriteria2005reg.pdf. [Accessed 2013 May 3].

[14] Egyptian organization for standardization and quality control. Egyptian standards frozen meat, Egypt, E.S 1522_2005, [Internet]. Available from; http://www.eos.org.eg/public/ar-eg/, [Accessed 2013 May 13]. 
[15] Egyptian organization for standardization and quality control. Egyptian standards fresh meat, Egypt, E.S 4334_2004, [Internet]. Available from; http://www.eos.org.eg/public/ar-eg/, [Accessed 2013 May 13].

[16] Cetin O, Bingol EB, Colak H, Ergun O, Demir C. The microbiological, serological and chemical qualities of mincemeat marketed in Istanbul, Turk J Vet Anim Sci. 2010; 34(4): 407-12.

[17] Sofos J.N.: Microbiological growth and its control in meat, poultry and fish. P.359-403, Blackie Academic and Professional, Glasgow, United Kingdom. 1994.

[18] Narashima Rao D., Ramesh BS.: Microbial profiles of minced meat. Meat Sci., 1988, 23, 279291.

[19] Sofos, J. N., Kochevar, S. L., Bellinger, G. R., Buege, D. R., Hancock, D. D., Ingham, S. C, et al.1999a. Sources and extent of microbiological contamination of beef carcassesin seven United States slaughtering plants. J. Food Prot. 62:140-145.

[20] Sofos JN, Cabedo L, Zerby H, Belk KE, Smith GC. Potential interactions between antioxidants and microbial meat quality. In Proceedings: Dietary Strategies for Improving Muscle-based Food Products. John Wiley \& Sons, Inc., New York. 1999.

[21] Alberle ED, Forrest JC, Gerrard DE, Mills EW. Principles of meat science (4 ${ }^{\text {th }}$ ed.), Kendall/Hunt Publishing Company, USA 2001.

[22] Mohammad A, Rajput IR, Khaskheli M, Faraz S, Devrajani K, Fazlani SA. Evaluation of microbial quality of goat meat at local market of Tando Jam. Pakistan J Nutr. 2010; 9(3): 287-90.

[23] Gill CO, Deslands B, Rahn K, Houde A, Bryant J. Evaluation of hygienic performance of processes for beef carcass dressing at 10 packing plants. J Applied Microbial. 1998; 84:1050-8.

[24] Khalafalla FK, Gergis AF, El-Sherif A. Effect Bacteriological quality of ground meat in Ankara. J. of freezing and mincing technique on microbial load. Vet Med Ankara Uni. 1993; 27: 45-63.

[25] Mousa MM, Awad HA, Yassien NM, Gouda HI. Microbial quality of some meat-products. Vet Med J-Giza. 1993; 41(3): 59-62.

[26] Elmali M, Yaman H. Microbiological Quality of Raw Meat Balls: Produced and Sold in the Eastern of Turkey. Turkey Pakistan Journal of Nutrition. 2005; 4 (4): 197-201.

[27] Duitschaever CL, Arnott DR, Bullock DH. Bacteriological quality of raw refrigerated ground beef. J. Milk Food Tec. 1973; 36: 375-7.

[28] Siriken B. The microbiological quality of ground beef in Aydin and Afyon Provinces. Turkey Revue Méd Vét. 2004; 155(12): 632-6.

[29] Heredia N, García S, Rojas G, Salazar L. Microbiological condition of ground meat retailed in Monterrey, Mexico. J Food Prot 2001; 64 (8):1249-51.

[30] Eisel WG, Linton RH, Muriana PM. A survey of microbial levels for incoming raw beef, environmental sources, and ground beef in a red meat processing plant. Food Microbiology. 1997; 14: 273-82.

[31] Buttiaux R, Mossels DA. The significance of various organisms of faecal origin in foods and drinking water. J Appl Bacteriol. 1961; 24: 353-64.

[32] Tompkin RB. Indicator organisms in meat and poultry products. Food Technol. 1983; 37: 107-0.

[33] Davidson, C., S. S. Reilly, E. Harp, S. E. Gilliland, and P. M. Muriana. 1999. Incidence of Esherichia coli, Listeria monocytogenes, Campylobacterspp and Salmonella spp. in ground beef and on beef carcasses in Oklahoma, abstr. 79C-17. Ann. Meet. Inst. Food Technol., Chicago, IL, 24 to 28 July 1999.

[34] Sancak YC, Boynukara B, Agaoglu S. The microbiological quality of ground meat marketed in Van. Yuzuncu Y1l Univ. Vet Fak Derg 1993; 4: 73-86.

[35] Westhoff D, Feldstein F. Bacteriological analysis of ground beef. J Milk Food Tec. 1976; 39: 401- 4.

[36] Tekinsen CO, Yurtyeri A, B. Mutluer. Bacteriological quality of ground meat in Ankara. J Vet Med Ankara Uni. 1980; 27: 45-63. 
[37] Mead GC. Microbiological hazards from red meat and their control. British Food J. 1994, 96, 3336.

[38] Cohen N, Filliol I, Karraouan B, Badri S, Carle I, Ennaji H, Bouchrif B, Hassar M, Karib H. Microbial quality control of raw ground beef and fresh sausage in Casablanca (Morocco). Journal of Environmental Health. 2008; 71(4):51-5.

[39] Hussein HS. Prevalence and Pathogenicity of Shiga toxin producing Escherichia coli in beef cattle and their products. J Anim Sci. 2007; 85: E63-E72.

[40] Hinton M, Coombs E, Tucker V, Jones S, Allen V, Hudson WR, et al. The bacteriological quality of British beef 2. Frozen minced beef. Meat Science. 1998; 50(4):395-402.

[41] Noveir MR, Dogan HB, Halkman AK. A note on Escherichia coli O157:H7 serotype in Turkish meat products. Meat Sci. 2000; 56; 331-5.

[42] Schroeder CM, Naugle AL, Schlosser WD, Hogue AT, Angulo FJ, Rose JS, et al. Estimate of illnesses from Salmonella enteritidis in eggs, United States, 2000. Emerging Infectious Diseases, 2005 January [cited 2009 August 18]. Available from http://www.cdc.gov/ncidod/EID/vol11no01/04-0401.htm.

[43] Okonko IO, Ogun AA, Adejoye OD, Ogunjobi AA, Nkang AO, Adebayo-Tayo BC. Hazards analysis critical control points (HACCP) and Microbiology qualities of Sea-foods as affected by Handler's Hygiene in Ibadan and Lagos, Nigeria. African Journal of Food Science. 2009a; 3(1):035-050.

*Corresponding author.

E-mail address: aiada.micro@gmail.com 